Tasarım çevrelerinde "biçim işlevi izler"

sloganıyla baş köşeye yerleştirilen tasarımın geleneksel işlev anlayışının, nerdeyse tek ölçüt olduğu dönemin tasarımlarında bile, gerçekte asıl gözetilen olgunun "işlevsel tasarım" mesajı ya da anlamının aktarıldığ bir biçem olduğunu șimdi görebiliyoruz. İnsan yapımı nesnelerin, bu arada teknolojimizin ürettiği endüstri ürünlerinin de başından beri toplumumuz için belli bildiriler taşıdığı, belli anlamlara konı olduğu kuşku götürmez. Neredeyse anlamdan kurtulan hiç bir şeyin olmadığg söylenebilir. Hiç bir anlam taşımıyormuş gibi görünen bir ürün bile, en azından "hiç bir anlam taşımama" anlamını iletir. Günlük kullanım nesneleri dediğimiz endüstri ürünlerini, yöneldikleri kullanım işlevlerinin içinde görmeyi, bu işlevlerin karşılığı olarak algılamayı o denli benimsemişizdir ki, onların illede birer anlam aktarıcısı, ya da iletişimin taşıyıcısı olduğu gerçeğini gözardı ederiz. Oysa nesnenin kullanım işlevini karșılaması, kullanıșlı

olması ya da ergonomik olması, her endüstri ürününde bulunması gereken, nesnenin olmazsa olmaz koşuludur. Gerçekte kullanıcının ürün seçimlerinin dayanağı, iletişimsel işlevler dediğimiz ürünün nelikliğine özgü anlamlamalardır. Kullanım nesneleri üzerinde konumlanan anlamlamalar ya da nesnelerin belli iletişimlerin taşıyıcısı olması, insanın uygarlığı kadar eski olsa gerek. Ne varki anlam olgusunun bilim alanının araştırma nesnesi olması ve anlambilimin kuruluşu yeni olduğu gibi;

nesnelerin belli iletişimlerin ve anlamların taşıyıcısı olduğu, nesnelerin taşıyıcısı olduğu iletişimin göstergebilim yolu ile araştırılmas

ve bu açıdan görülüp değerlendirilmeleri gerektiği düşüncesi de tasarım çevrelerinde oldukça yenidir ancak giderek kabu görmektedir.

Abstract

The field of Industrial Design is a technique-art applying one which is directly influenced by the scientific and technological as well as artistic developments and artistic thinking, as it is seen in many other fields. In fact every drop that falls in the pool of science, art and technology reach

es in waves every field. And today, parallel to

the speed of communication this interaction is increased.

Because of its nature, Industrial Design i. affected by the technological developments rapidly. Our era witnessed the transition of the technology from the mechanic and mechanism technology to the electro-mechanic and from thence to the electronic and in the last twenty years to the micro-electronic technology. No other technological passing has influenced the field of design as much as the micro-electronic technology has done. While this kind of technol-

ogy gives the designer a great opportunity of shaping, it also makes the means which he rests on in the processes of shaping and designing invalid. The loss of model which results from the
Prof. Dr. Oğuz BAYRAKÇI

Mimar Sinan Güzel Sanatlar Üniversitesi

Mimarlık Fakültesi

Endüstri Ürünleri Tasarımı Bölümü

\section{Göstergebilimsel Araştırma Alanı olarak Ürün Tasarımı}

Giriş:

İletişim etkinliği uygarlığımızın ve kültürümüzün temel yapıtaşıdır. Çağdaş uygarlık, çağdaş kültür dediğimiz olgunun düşünsel, davranışsal model ve tutumlarının da bir bölümünün görünen yüzünü oluşturan, insan yapımı çevrenin teknolojik ürünleridir. Bu nedenle de kültürü; "doğanın yarattıklarına karşı insanın yarattığı her şey" diye tanımlarız. Bu anlamda, günümüzde kent kültürü dediğimiz insan yapımı çevrede artık doğanın yarattıklarından daha çok, insanın ürettiklerinin yer aldığını söyleyebiliriz. Ne var ki insanın kendisi için ürettiğini düşündüğümüz çevrenin ve bu çevreyi oluşturan ürünlerin, sorunları çözmekten öteye, yeni sorun yumakları ördüğü de görülüyor. Güdümlü, rekabetçi pazarın ürettiği nesne yığınlarının getirdiği pek çok sorunlardan biri de "iletişimsizlik" ya da "yetersiz iletişim" olgusudur.

Psikoloji insan gereksinimlerinin basamaklı olduğundan söz eder. Toplumun da bu kuralın dışında kalamayacağı akla yatkındır. Bireysel düzlemde bakıldığında; yorgun bir kişi doğrudan duyum kuramına göre oturacağ yer konusunda seçici değildir. Ancak bu tür gereksinimleri doyurulmuş bir insan, normal durumlarda oturacağı yerin kendi sosyal kültürel konumuna, yapacağı işe ve işin yapılış tarzına uygun bir oturma elemanı beklentisi seçiciliğine girer. Benzer bir şekilde toplum da aynı tutumu benimser. Örneğin güvenlik gereksinimi karşılanmamış bir toplum, tümüyle iletişim amaçları taşıyan sosyal kültürel etkinlik ve beklentilerini erteleyebileceği gibi, iletişimsel açıdan yaşam tarzını ortaya koyan nesne kullanım alanındaki uygunluk kuralına dayalı seçici tutumunu da gözardı edebilir. Toplumun ve bireylerin aradığı bu uygunluk ilkesi iletişimsel süreçleri tanımlar. Nesnenin biçimsel niteliklerine bakılarak düşünülen işe, eyleme, sosyal kültürel öze uygun olup olmadığına ilişkin bir değer biçilir.

Nesnenin seçim sürecinde başlayan iletişim, nesnenin kullanım sürecinde de devam eder. Kullanıcı kendi konumuna bağlı olarak nesneye yakıştırdığı anlamları ve kendine ilişkin bilgiyi nesne üzerinden yansıtma çabasına girer. Ya da seçilen nesneye ve kullanım tarzına bakılarak kullanıcısına belli anlamlamalar uygun görülür.

Günlük kullanım nesneleri dediğimiz endüstri ürünlerini, yöneldikleri kullanım işlevlerinin içinde görmeyi, bu işlevlerin karşılığı olarak algılamayı o denli benimsemişizdir ki, onların illede birer anlam aktarıısı, ya da iletişimin taşıyıcısı olduğu gerçeğini gözardı ederiz. Oysa nesnenin kullanım işlevini karşılaması, kullanışlı olması ya da ergonomik olması, her endüstri ürününde bulunması gereken, nesnenin olmazsa olmaz koşuludur. Gerçekte kullanıcının ürün seçimlerinin dayanağı, iletişimsel işlevler dediğimiz ürünün nelikliğine özgü anlamlamalardır. Kullanım nesneleri üzerinde 
konumlanan anlamlamalar ya da, nesnelerin belli iletişimlerin taşıyıcısı olması, insanın uygarlığı kadar eski olsa gerek. Ne var ki, anlam olgusunun bilim alanının araştırma nesnesi olması ve anlambilimin kuruluşu yeni olduğu gibi; nesnelerin belli iletişimlerin ve anlamların taşıyıcısı olduğu, bu açıdan görülüp değerlendirilmeleri gerektiği düşüncesi de tasarım çevrelerinde oldukça yenidir.

Tasarım çevrelerinde "biçim işlevi izler" sloganıyla baş köşeye yerleştirilen tasarımın geleneksel işlev anlayışının, nerdeyse tek ölçüt olduğu dönemin tasarımlarında bile, gerçekte asıl gözetilen olgunun "işlevsel tasarım" mesajı ya da anlamının aktarıldığı bir biçem olduğunu şimdi görebiliyoruz. İnsan yapımı nesnelerin, bu arada teknolojimizin ürettiği endüstri ürünlerinin de başından beri toplumumuz için belli bildiriler taşıdığı, belli anlamlara konu olduğu kuşku götürmez. Neredeyse anlamdan kurtulan hiç bir şeyin olmadığı söylenebilir. Hiç bir anlam taşımıyormuş gibi görünen bir ürün bile, en azından "hiç bir anlam taşımama" anlamını iletir.

Ürünler üzerindeki iletişim ve anlam olgusunun bu denli yaygınlığına karşın bir tasarım sorunu olarak algılanması, yetmişli yılların ortalarından itibaren teknolojide yaşanan değişim sonrasında mümkün olmuştur. Mikro-elektronik teknolojisinin geliştirdiği yeni ürün profilinin taşıdı̆̆ı iletişim sorunu, tasarım çevrelerinin anlayışını derinden etkilemiştir. Kompakt devreler sayesinde, tasarımcının dilediğince sarabileceği aşırı küçültülmmüş içler oluşturmuştur. Yeni işlev ve işleme türleri birbirinden ayrımsız kutular içine konulabilmiştir. Böylece, işlev mantığına dayalı tasarım örnekçesi yok olurken, iletişim çağı diye adlandırılan günümüzde, çağdaş toplumun ürünlerinde önemli bir iletişim sorunu doğmuştur.

Yüzyılımızın iletişim çağı olarak adlandırılması, teknoloji de olduğu kadar iletişim kuramlarında ki gelişmelerin etkisini de taşır. Tasarımı etkilemeleri ve bu alana konumlanabilmeleri açısından bakıldığında, çağdaş iletişim alanında Dilbilim, Göstergebilim ve Anlambilimi'nin ayrı yerleri vardır. Tasarım alanında özellikle anlambilimsel yaklaşımlardan yola çıkılarak, Ürün Anlambilimi'nin oluşturulması çabaları gündemdedir. Çalışmaların henüz çok yeni olmasına karşın elde edilen sonuçlar, bu alandaki beklentileri güçlendirmektedir.

Her bilim dalı kendi öngörü ve varsayımlarına dayalı olarak gerçekliği temsil eden, onu anlamamıza yarayacak bir örnekçe/model (paradigma) kurar. Böylece, her defasında herşeyi baştan açıklama gereği kalmaz. Daha önce tanımlanmış kavram ve olgulara dayanarak ilerlemek mümkün olur. Göstergebilim de; "külttürün temelinde yatan iletişim, gösterge, dizge olgusunu açıklarken böyle inandırıcı bir paradigma kurabilmiş, dolayısıyla dil, kültür ve iletişim konusundaki çalışmaların hızlanıp gelişmesini sağlamıştır" (Erkman, 1987).

Göstergebilimin, "İletişim çağı" da denilen yüzyılımızda doğmuş olması rastlantı sayılamaz. İletişim olgusunun yaşamsal değer kazandığı günümüzde böylesi bir gelişme çağın gereksinimidir. Günlük yaşamın sağlıklı sürdürülmesi bile bir takım gösterge dizgelerinin ilettiği anlamların bilinmesini gerektirir.

Günümüzde endüstri ürünlerinin yeterli ve etkili kullanımı da neredeyse ortalama kültürlü insan kavramının üzerinde yetenek gerektirmektedir.

Öte yandan teknolojik örnekçenin yanı sıra ürün tasarımı ve kullanım örnekçesinin de değişmiş olması zaten ürünler üzerindeki iletişim sorununu gündeme getirmiştir. coming of the micro-electronic technology

caused a new product profile which puts product communication into the foreground and bears communicational problems and in addition to this it left the designer facing the new problem by making his means invalid. Anahtar Kelimeler:

Ürün tasarımı, Ürün işlevi, Ürün iletişimi, Ürün okuması, Göstergebilim, Göstergesel işlev Keywords:

Product design, Product function, Product communication, Product understanding, Semiotics, Semiosi

2 Sayı II-I2, 2011 
Çağımızın genel iletişim sorunlarına olduğu kadar, günlük kullanım ürünlerinin üzerinde konumlanan anlamlama sorununa da yeni yaklaşımlar getiren bir iletişim kuramıdır göstergebilim. Kendi içinde tutarlı bir model geliştiren göstergebilim, hemen her türden kültürel sosyal görüngüleri inceleme kapsamına alır. Eco'nun deyişle; "Tüm kültürel olgular gösterge dizgeleridir" (Umberto, 1980). Kültürel boyutu yadsınamayan tasarım olgusu ve endüstri ürünleri de göstergebilimsel inceleme alanına girer. Belirli farklılıklar taşımasına karşın tasarım olgusu ve ürünleri, göstergebilim modelinin uygulanmasına olanak verir.

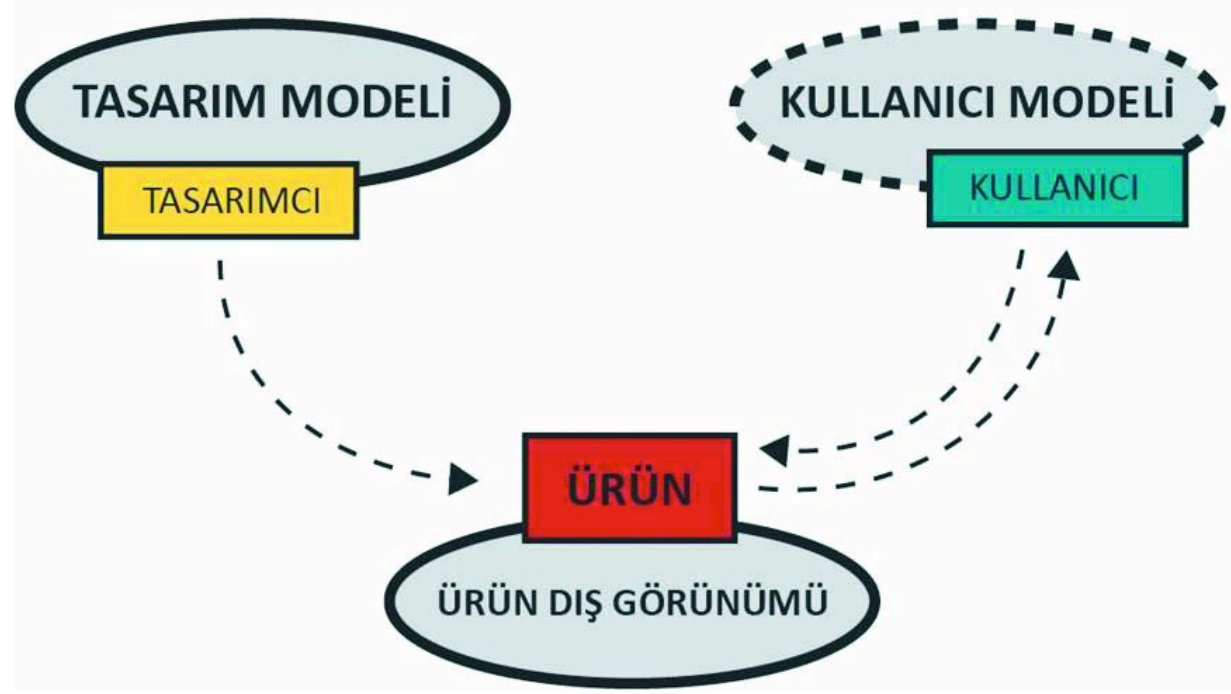

Şekil: 1 Tasarımda iletişim süreci

\section{Göstergebilim, gösterge kavramı ve kapsamı}

"Kültürü iletişim açısından inceleyen bilim dalı" diye'de tanımlanan göstergebilim içinde; gösterge kavramı merkezi bir öneme sahiptir. Gösterge "bir başka şeyin yerini alabilecek nitelikte olduğundan kendi dışında bir şey gösteren her türlü nesne, varlık ya da olgu" (Vardar, 1988 ) diye tanımlanır. İletişim etkinliği açısından açıklayıcı olan diğer bir tanım ise göstergeyi bir "aracı" olarak tanımlar; "Kendisi o şey olmadığı halde, o şeyi çağrıştırarak iletişim sağlayan her aracı bir göstergedir" (Erkman, 1987).

Bu tanımlardan da görüleceği gibi, endüstri ürünlerini de içine alacak bir şekilde, çevremizdeki hemen herşeyi gösterge sayabiliriz. Gösterge dizgelerini inceleyen bir bilim dalı olarak, göstergebilim, çok geniş bir alanı kapsıyor. Göstergebilimin içindeki farklı görüşler nedeniyle, her kuramsal farklı bilginin bağımsız bir göstergebilim okulunu temsil ettiği dile getirilmekle birlikte, ana görüşler açısından dört göstergebilim okulu belirginleşir (Vakeva, 1990).

1- Deneysel Göstergebilim (Empirical Semiotics) Arkaik Grek tıbbı: Thure Von Uexkull

2- Felsefi Göstergebilim (Philosophical Semiotics) A.B.D. göstergebilim okulu: Charles

Sander - Peirce

3- Dilbilimsel Göstergebilim (Linguistic Semiotics) Paris göstergebilim okulu: Ferdinand de Saussure 
4- Uygarlık Göstergebilimi (The Semiotics of Culture) Moskova göstergebilim okulu: Yuri Lotman.

Farklı göstergebilim okulları, düşünceleriyle anlamlı bir şekilde değişik terimce ve yapı kullanırlar. Peirce göstergeyi bir "Üçlü birlik" olarak tanımlar. Oysa Saussure göstergeyi "İkili ilişki" içinde ele alarak açıklar. Yapısal anlambilimin öncüsü Greimas ise anlambilim tartışmalarında göstergeye hiç bir şekilde gereksinim duymamıştır. Yuri Lotman, tüm insan uygarlığını kendi "göstergesel küresi" (semiosphere) içine alır. Çeşitli görüntü, olgu ve olayları, dili kapsayarak, sanatsal anlatım ve gerçeğin imgesi arasındaki ilişkiye dayanarak inceler. Bunlardan başka özgün yaklaşımlarıyla dikkat çekenler Barthes ve Sebeok'dur. Barthes mitlerin yapısını ortaya çıkarır. Sebeok ise, hayvanlar arasındaki iletişimi incelemiştir.

Göstergebilim çevrelerinde aynı tutarlı kuramı kullandığı kabul edilen Greimas'ın düşünce tarzı, modern göstergebilimde en kesin ve yalın olanlardan biri olmasına karşın, yaygın olarak öğrenilmesi en zor olanlardan biridir.

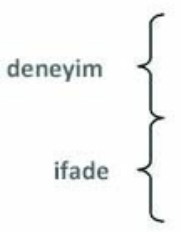

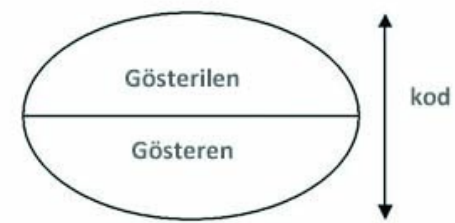

(a)

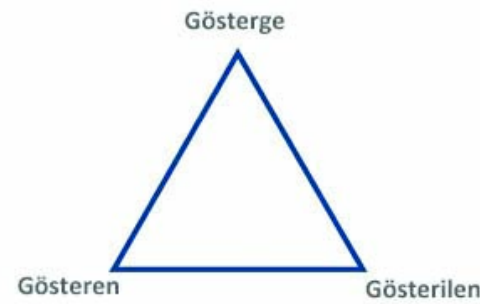

(b)
Şekil: 2 Saussure’ün ikili göstergesi (a) Peirce'in üçlü göstergesi (b)

\section{Göstergenin bileşenleri}

Her göstergenin "bir içerik bir de biçim"i vardır. Bu bileşenler, ayrı ayrı birer dizge alanına sahiptir. İçerikle bağlantısı kurulamamış biçim tek başına anlam taşımaz. Biçimle bağlantısı kurulmamış kavram da ifade edilemeyeceğinden iletişim açısından bir değer taşımaz. İletişim işlevini yitirir. Toplumsal iletişim işlevi açısından anlamlamanın gerçekleşmesi için; biçimle içerik arasında bir bağlantının kurulabilmesi gerekir. Genel göstergebilim kuramı açısından gösterge üçlü bir ilişki olarak tanımlanmıştır. Saussure; biçimi gösteren, içeriği ise gösterilen kavram çiftiyle ifade eder. Hjelmslev ise, içerik tanımını aynen kullanırken, biçim'e anlatım kavramını getirir. Hjelmslev'in bir diğer önemli yaklaşımı ise anlamlama düzlemlerine getirdiği yeni tanımlardır. Göstergelerin eklemlenerek "mecaz" anlamlar üretmesini düzanlam (denotation) yananlam (connotation) kavram çiftiyle açıklar. Saussure'ün göstergeyi birbirinden ayrılmayan ikili bir yapı olarak tanımlaması, malzemeye dayalı göstergelerde sorunlar taşır. Bu sorunlar düzanlam /yananlam kavram çiftine dayanarak, ürün göstergesinde işlev düzlemlerinin ayrılıp tanımlanmasıyla aşılabilmektedir (Bayrakçı, 1985/1), (Bayrakçı, 1985/2).

Ürün göstergesi; düzanlam düzleminde temel kullanım işlevine (birincil işlev) göndermeler yapar. Yananlam düzleminde ise (ikincil işlevler) ürün biçiminde konumlanan kültürel sosyal olgulara göndermeler yapar. 

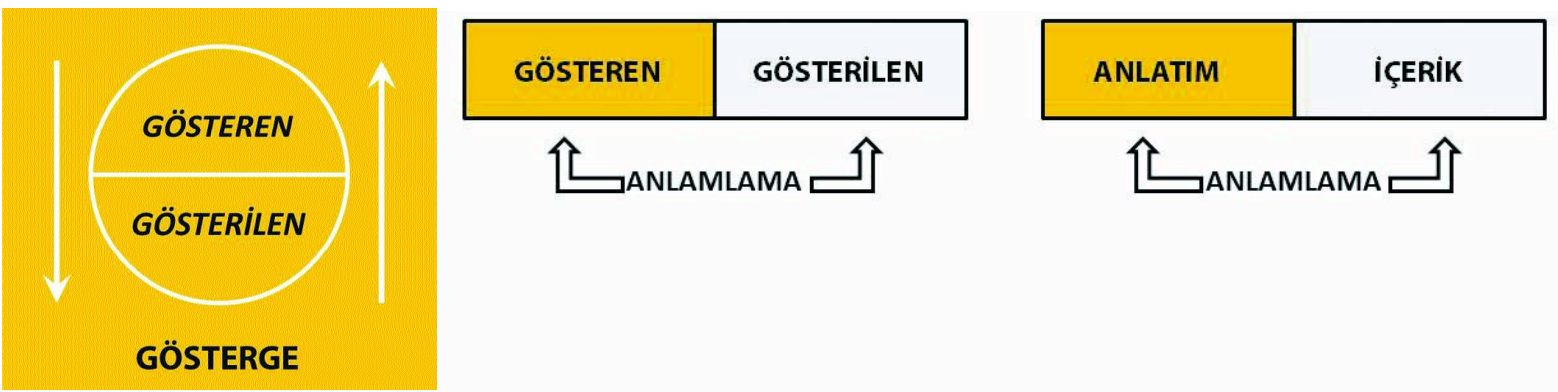

GÖSTERGE

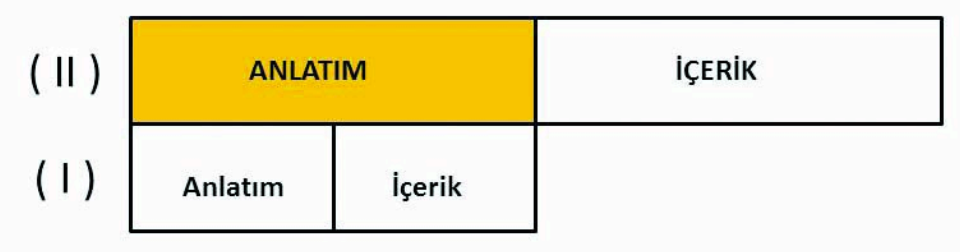

Şekil: 3

TASARIMDA IŞLEV DÜZLEMLERININ EKLEMLENMESI, ANLAMLAMANIN YAPISI

\begin{tabular}{|c|c|c|c|c|}
\hline $\begin{array}{l}\text { Birincil İşlevler } \\
\text { (Düzanlam) }\end{array}$ & ANLATIM & IÇ̧ERIK & NESNE - віçімі & $\begin{array}{c}\text { TEMEL } \\
\text { KULLANIM IŞLEVI } \\
\end{array}$ \\
\hline Düzlemi & & & & \\
\hline $\begin{array}{l}\text { İkincil İşlevler } \\
\text { (Yananlam) } \\
\text { Düzlemi }\end{array}$ & ANLATIM & İÇERIK & NESNE BÜTÜNÜ & $\begin{array}{l}\text { TOPLUMSAL KÜLTÜREL } \\
\text { BiçiM DAĞARI }\end{array}$ \\
\hline
\end{tabular}

Saussure'ün ikili gösterge kuraminda ürün göstergesinde anlamlamanin yapısı ve işlev düzlemlerinin (birincil işlev-düzanlam/yananlam-ikin-

cil işlevler) eklemlenmesi

Şekil: 4

Tasarımda işlev düzlemlerinin eklemlenmesi ve anlamlamanin

yapisı
(II)

(1)

\begin{tabular}{|l|l|l|}
\hline \multicolumn{2}{|c|}{ ANLATIM } & \multirow{2}{*}{ IÇERIK } \\
\hline Anlatım & İçerik & \\
&
\end{tabular}

\begin{tabular}{|l|l|l|}
\hline \multicolumn{2}{|c|}{\begin{tabular}{|l|l|}
\multicolumn{2}{|c|}{ TASARIM } \\
NESNE BÜTÜNÜ
\end{tabular}} & $\begin{array}{l}\text { TOPLUMSAL KÜLTÜREL } \\
\text { BiçiM DAĞARI }\end{array}$ \\
\hline $\begin{array}{l}\text { Nesne } \\
\text { Biçimi }\end{array}$ & $\begin{array}{l}\text { Temel } \\
\text { Kullanım İşlevi }\end{array}$ & \\
\hline
\end{tabular}

Şekil: 4

\section{Göstergelerin sinıflanması}

Peirce, göstergeleri üçlü ilişkilere dayalı olarak,

10 ayrı üçlükte topladığı 30 türe ayırarak sınıflar. Önerdiği üçlükler içinde bizi en çok ilgilendiren, göstergenin gönderme yaptığı gerçek nesneyle olan bağıntısına dayanarak yapılan sınıflandırmadır (Erkman, 1987), (Vihma,1992). Peirce, bu üçlüde özellikle dilsel göstergelerden uzaklaşır. Gönderme yaptığı gerçek nesneler ile bağıntıları açısından göstergeyi ele alması nedeniyle ürün göstergesini en çok ilgilendiren üçlü budur.

1-Belirti (Index)

2-Görüntüsel gösterge (Icon)

3-Simge (Symbol) 


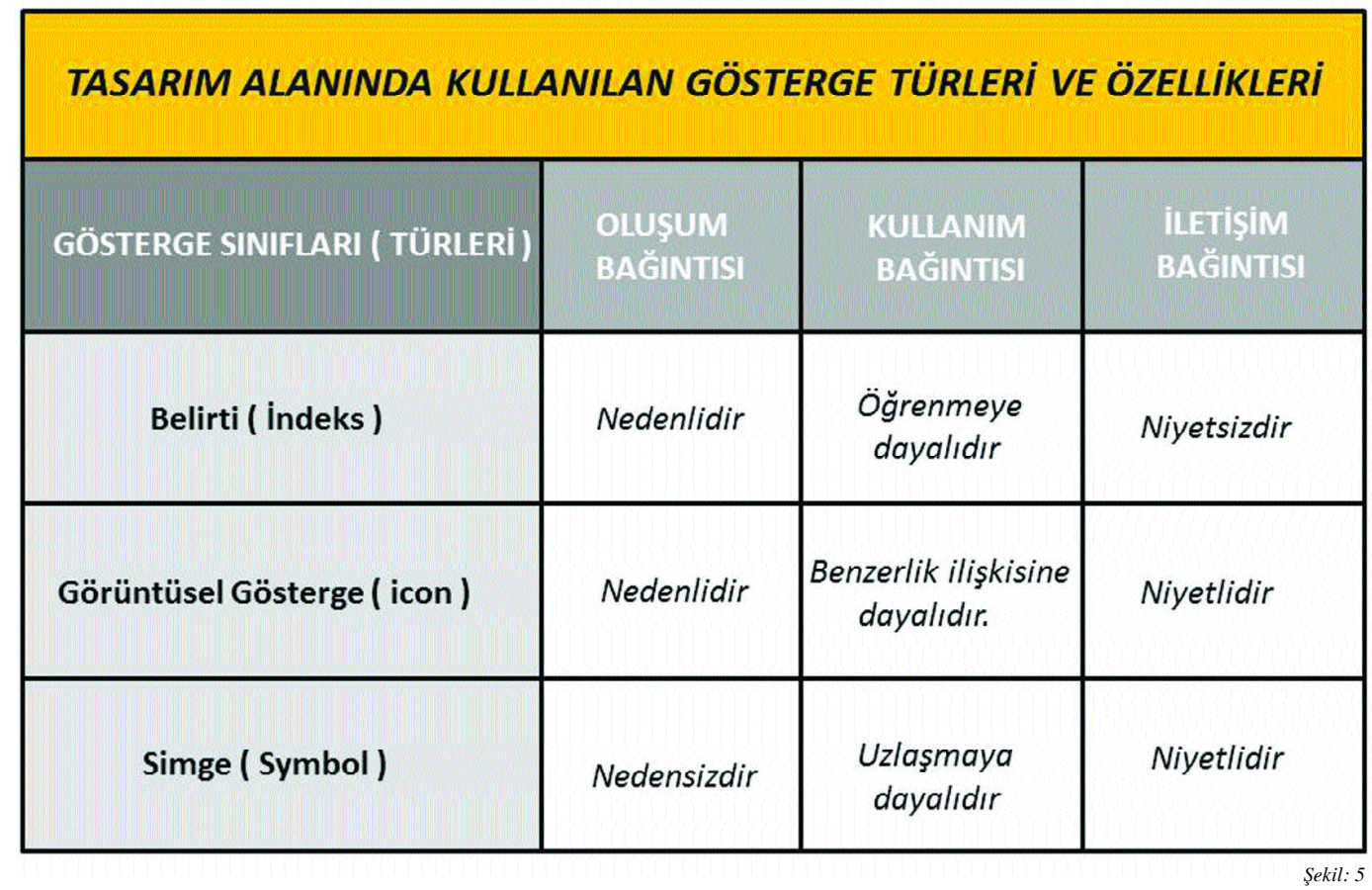

\section{Göstergebilimsel araștırma alanı olarak tasarım}

Ürünleri birer gösterge (sign) olarak görmek tasarımda henüz yeni bir düşünce yoludur. $\mathrm{Bu}$ görüş ürünlerin kendi bütünlükleri ve çeşitliliklerini daraltan bir düşünce yolu olarak görülebilir. Ancak "tasarımdaki göstergebilimsel sorunlar tüm endüstri tasarımı alanını kaplar. Bunlar bütün tasarım nesneleri, süreçler, etkinlikler, araçlar, yöntemler, amaçlar, durumlar ve benzerleri olabilir. Göstergebilimsel anlamlarla tanımlanan tasarım, bütün düzeylerde ve alanlarda mümkün ve gereklidir" (Oehlke, 1990).

Endüstri tasarımının ve ürünlerinin değişik yön ve sorunları göstergebilim içinde üç alanda ele alınır (Kutschinski-Shuster, 1990).

Sözdizimsel/tümcebilimsel düzeyde; ürünlerin konstrüksiyon ve strüktürlerinin biçimlenişi. Anlambilimsel düzeyde; biçimlerin ve ürünlerin anlamları. Edimsel/edimbilimsel düzeyde; tüketim ve sahip olma (iyelik) ilişkileri incelenir.

Strüktürel elemanlar, işlevsel etki ve etkinlikler ile nesnenin total biçimi (gestalt) ve görünüşü tümüyle süreçlerle bağlantılıdır. İlkesel olarak; tüm endüstri tasarımı alanı ile onun strüktürel ve işlevsel bağlantıları ve ilişkileri göstergebilimsel araştırmanın öznesi yapılabilir. Bu tutum; tasarım eylemi, onun işlevleri, yapısı ve tasarım nesnesinin temsil ettiği olgular arasındaki karmaşık bağlantıya bütünsel bir yaklaşımı amaçlar. Göstergebilim tasarım nesnelerinin tüm düzeylerinde, üretim aşamalarının tümünde ve ürünlerin tüketilmesinde kısaca her düzeyde varlığını sürdürür.

Göstergebilim; ürünlerin ve tasarım alanının üç temel görünümlerinin tümünde etkin bir açıklayıcıdır. Sözsüz ürün dili olarak toplumsal grup ya da bireylere iletişimin taşınması, kullanıc1-ürün arayüzünün araç-işlem optimizasyonu, estetik kavrayış vb. konularda yeni özgün açıklamalar getirmektedir. Göstergebilim yeni bir disiplin değildir. Ancak tasarıma uygulanması oldukça yenidir. Tasarım açısından önemi, teknolojideki yaygın gelişme ve 
Şekil: 6

Tasarım sorunlarının

ele alındı̆̆ı

göstergebilim

alanları.

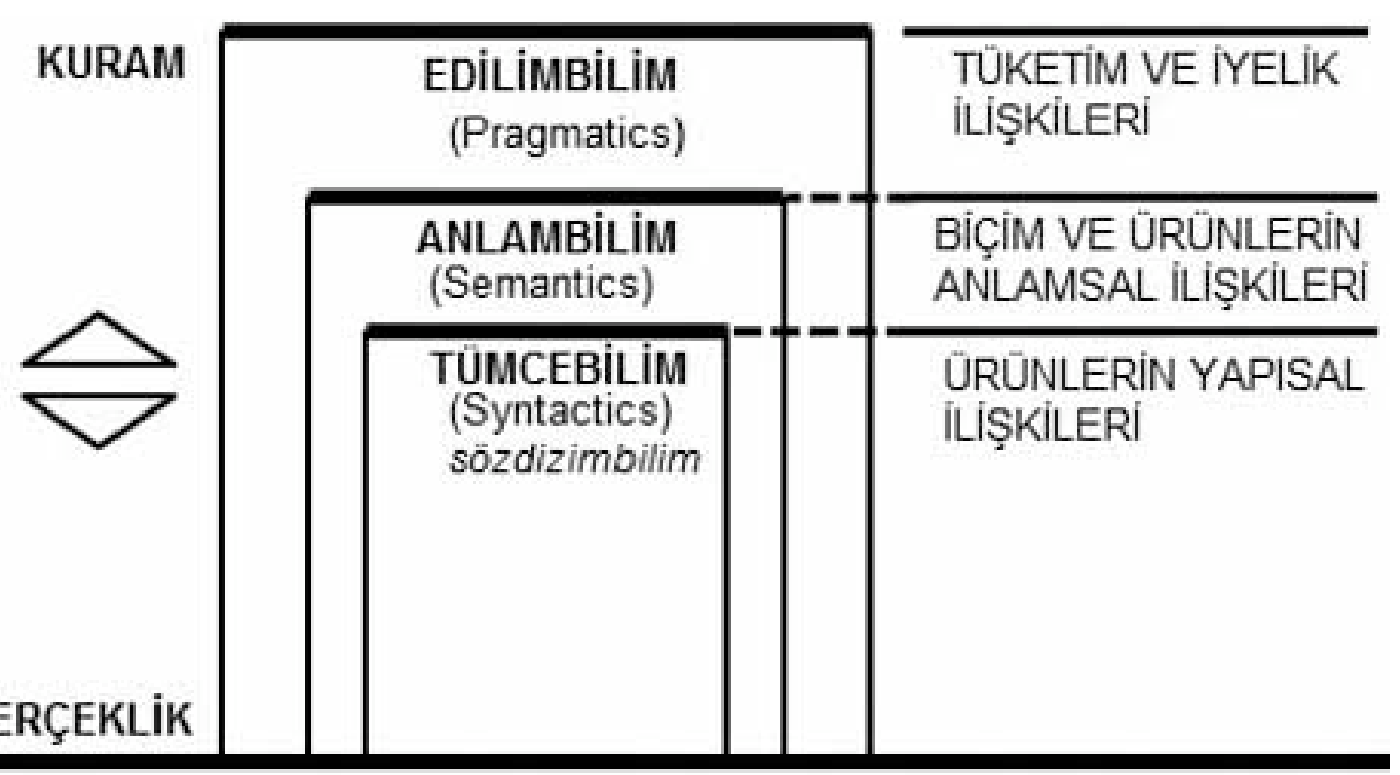

Şekil: 6
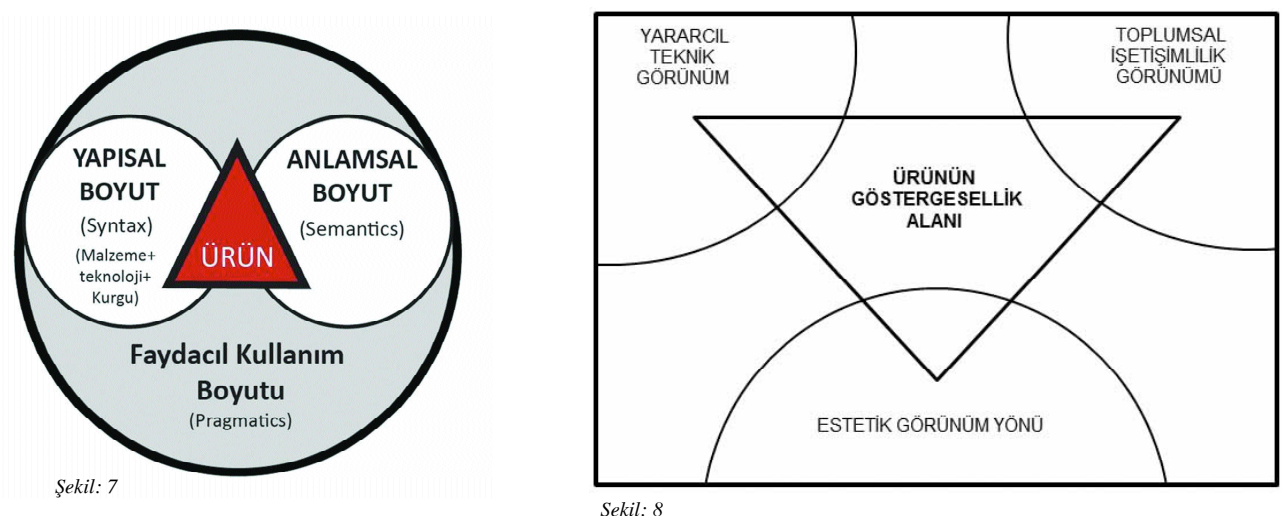

örnekçe değişimi, bunun tasarım felsefesinde yarattığı değişim, pazarlama ve tüketim eğilimleri ve medyanın yaygın etkisi ile artmıştır.

\section{5. Ürünlerin göstergesel karakteri}

"Malzemeye dayalı gösterge aracı" (material sign vechicle) olarak tanımladığımız ürün göster-

Şekil: 7

Ürünün algilanması, anlaşılması

ve temsil edilmesine

yol gösteren

boyutları

sekil: 8

Ürünün göstergesellik

alanı (semiosis) gesi, göstergebilim alanına giren pek çok göstergeden ve dil göstergelerinden farklı bir göstergedir. Kendine özgü sorunlar taşır. Genel gösterge kavramında, göstergenin gösteren kesimi göreli somut anlatımlar olabilir, ancak göstergenin gösterilen kesimi daima soyut, kavramsal bir içeriktir.

Ürün göstergesinde ise gösterge taşıyıcısı somut, nesnel bir varoluş olarak algılanma riskini taşır. Ya da göstergenin nesnesi varoluşun doğrudan salt kendisi gibi algılanabilir. Bu riskler nedeniyle gösterge kendine dönebilir, yani gösterge yine kendine gönderme yapıyor gibi algılanabilir. Bunlar üçlü gösterge kuramına özgü risklerdir. İkili gösterge kuramında ise gösteren ile gösterilen kesimlerinin belirlenme zorluğu vardır. Yananlamlamalar nedeniyle kendi aralarında yer değiştirebilirler. Endüstri ürünleri kültürel, sosyal gerçeklikleri nedeniyle anlam taşıyıcı biçimlerdir. Bu özelliğiyle ürün, bir 
gösterge olarak, gösterge'nin tüm niteliklerini taşır.

Ürünün biçimi ya da biçim nitelikleri gösterenin/gönderenin (anlamlamanın) bir taşıyıcısı (araç-means) veya tarzına ilişkin bir özelliktir (Kip-mode). Biçim nesneye gönderen bir araçtır. Biçim kimi nesneye gönderme yapan bir araçtır. Biçim nesneye değişik yollarla gönderme yaptığg 1 gibi nesnenin değişik türlerine de gönderme yapar. Bu ilişki gösterge türlerinden biri olabilir (belirti-simge-görüntüsel gösterge) (Vihma, 1990).

Eğer bir ürünün biçimiyle sadece kendinde ürün olarak adlandırabilinen bir şeye gönderme yaptığını kabul edersek, durum oldukça basit olurdu. Bunun anlamı; işlevin zihinde canlandırılabilmesi için, birisinin ürünü kasıtlı olarak kullanarak bize işlev hakkında bilgi veriyor olması gerekirdi. Böyle bir kullanım ise hiç bir şey içermez, fakat bilinen işlev biçimde görünür, ortaya çıkar. Bu görüş şüphesiz yanlıştır. Kullanıcı ürün ilişkisi çok daha çeşitlilik taşımaktadır. Algılama anlama ve kullanım bunları değiştirir.

Eğer bir gösterge olarak ürün sadece kendine gönderme yapsaydı, o zaman ürün bazı temel maksat ve işleve sahip olmak zorunda olacaktı. Bu ideal veya en uygun bir işlev olacaktı. Açıkça bir gösterge olarak ürün sadece tek bir ideal işleve gönderme yapamaz. Tersine, bir ürün pek çok yoldan yorumlanabilir ve gerçekte değişik yorumlar söz konusudur. Bir gösterge olarak ürün sadece kendisine ve belirli ideal bir işleve gönderme yapmaz, fakat pek çok işlevlere ve kullanımlara olduğu kadar kendisinin kaynağı olarak pek çok diğer şeylere de gönderme yapar. Bunlar onun kullanım alanı, ait olduğu çevre, kullanıcı grupları, diğer bazı nesneler, bir gelenek, karakter ve benzerleri olabilir.

Şimdi bu kurallamaları, göstergeye konumlandırdığımız bir ürün üzerinde örnekleyerek tartışalım. Seçtiğimiz ürün, pazardaki buharlı ütü setinden oluşsun. Buharlı ütü, pek çok ütüden, belirli bir tiptir. Ürünleri belirli bir tip olarak kabul etmek onların takdim edilen işlev ve işleme tarzlarına uygun bir biçime sahip olmalarıyla mümkündür. Buharlı ütü biçimi ayrıntılarının yanı sıra genelde; sıcaklığı ve buharı transfer eden üçgenimsi metal yüzeyi, tutma yönetme işini gören bir köprü sap, bunun altında, termostatlı işlem tercih
Şekil: 9

Peirce'in üçü gösterge kuramında ürün göstergesi

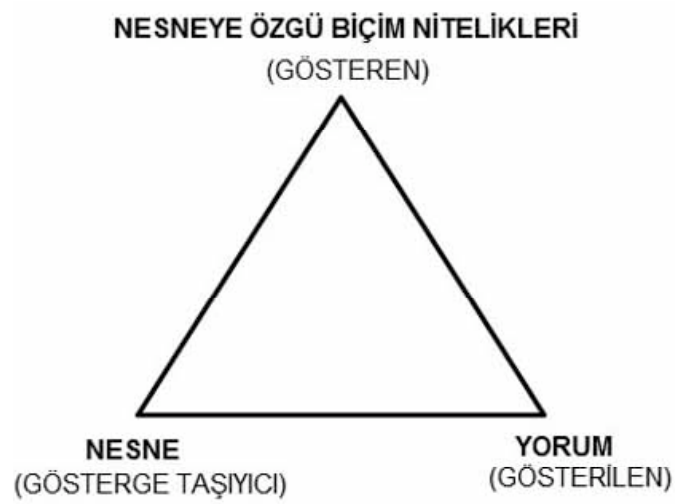

Şekil: 9

8 sayı 11-12, 2011

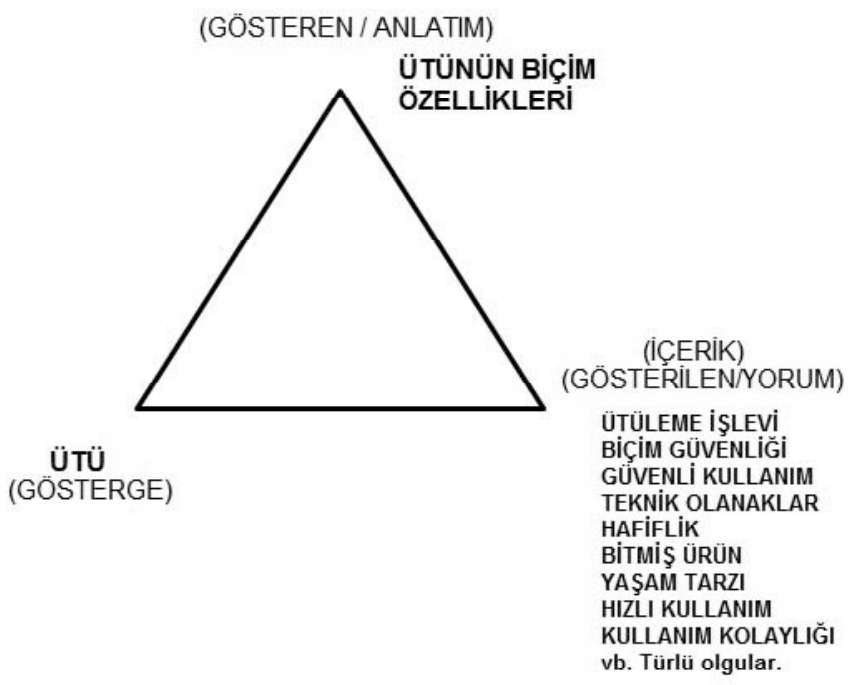


silindiri ve arkasında kablo sarma ve oturma yüzeyi bölümlerinden oluşur. Biçimin bu yapısal ilişkilerinden başka firma ve ürün kimliğini ileten biçemlerden, renk doku ve biçim çizgilerinden söz edebiliriz. Bu nitelikler de biçimle birlikte göndermeler yapabilir. Bu biçimsel özellikleri görünce ütüyü tanırız. Ütü bir göstergeyse, bu biçimsel özellikler de, bu göstergenin gösterenini oluşturur. Diğer bir deyişle, ütünün biçimi ve biçim özellikleri anlatımıdır.

Ütünün bütün bu biçimsel özelliklerinden oluşan gösterenine bakıp da, gösterileni için yine ütü diyemeyiz. Bu yanıt göstergebilim açısından saçmadır. Bir ürün kendi kendisinin göstergesi olamaz. Bu göstergenin tanımına ters düşer. Eğer gösterge kendisi dışında bir şey gösterecekse, ya da kendisi o şey olmadığı halde o şeyin yerini tutacaksa, ütü göstergesinin biçimsel özelliklerinden oluşan gösterenine bakıp, gösterilen kesimi için yine ütü diyemeyiz. Zira bu durumda gösterge kendi üstüne kapanacaktır. Bu durumda biz ütüden öteye hiç bir şeye ulaşamayacağız. Ürünlere özgü olarak ortaya çıkan bu sorun, yine kullanım nesnelerine özgü bir bakış açısıyla aşılır. Bir ürün göstergesi olan ütü, kendi kendisinin göstergesi değildir. Bir kullanım işlevinin göstergesidir. Ütü bağlamında bu "ütüleme işlevi"dir.

Sonuç olarak; ürün göstergesinin göstereni biçim ve biçim özellikleri, gösterileni ise ürünün kullanım işlevi ve ona eklemlenen kültürel sosyal olgulardır. Bir gösterge olarak her kullanım ürünü, biçimi aracılığıyla işlevine gönderme yapar. Bu arada pek çok olguya da gönderme yapar.

Ütü göstergesini yorumlayabilmek için "ütüleme işlevini" kavramsal olarak biliyor olmamız gerekir. Bu ütü göstergesinin "içerik düzlemini" öğrenmiş olduğumuz anlamına gelir. Ürün kullanımında bu ilk adımdır. İkinci adım; ütünün biçimiyle (gösteren) onun işlevi (gösterilen) arasındaki bağlantıyı da (anlamlama bağı) öğrenmiş olmamız gerekir. Biçimiyle işlevi arasında nedenlilik bağı bulunan ürün göstergesinin, kullanımının gerçekleşmesi, tanınması için bu iki adımı bilmek gerekir. Bir üçüncü adım ise ütünün sosyal kültürel türlü olgulara yaptığı göndermelerin yorumlanabilmesidir. Bunun için de, yine gösteren kesiminde yer alan biçim nitelikleriyle, gösterilen kesiminde bunları karşılayacak olası anlamlar arasındaki bağlantıyı bilmek gerekir.

Ürün göstergelerinin biçim ve işlev bağlantıları aslında çok küçük yaşlarda öğrenilmiş bir olgudur. Çevre ve kültür koşullarına da bağlı olarak, öğrenilen işlevleri ya da benzerlerini karşılayan benzer ürün ve tarzlar da yine küçük yaşlarda öğrenilir. Sonuç olarak ürün göstergeleri, işlevleri öğrenilmiş nedenli göstergelerdir. Diğer göstergelerden farklı olarak ürün göstergesinde bulunan bir başka özellik daha vardır. Aynı işleve yönelmiş pek çok ürün, farklı biçimlerde üretilir. Değişik dönem ve firmalara ait, aynı işleve yönelmiş ürün biçimleri arasında önemli değişiklikler vardır. Yani aynı işlevi değişik biçimlerle karşılamak tasarımın doğasında vardır. İşte ürün göstergesinin önemli farklarından biri budur. Aynı işlev değişik biçimlerle karşılanır. Burada yine öğrenmeye bağlı olan; düzgülenmiş (șifrelenmiş-coded) biçim dağarı karşılamaları ve gücül seçenekleri yatar. Ancak bu biçimlerin (gösterenlerin) hangi işlev ve anlamların karşılaması olduğu öğrenilmemişse ürünün (göstergenin) düzgüsü (şifresi) çözülemez.

Pratikte pek olası görünmese de; hiç buharlı ütü görmemiş biri, ütünün neye yaradığııı çözemeyebilir (Böylesi bir örnek kimi elektronik aygıtlar için daha olası görünüyor). Ütünün işlevine 
uygun çözümlenmediğini söylemek mümkün değil. Demek ki şifreyi çözmek için, biçimin işlevi karşılamış olması yeterli değil, yine de, bir öğrenme sürecine gereksinim var. Öte yandan ütüyü kullanmayan, ondan yararlanmayan birisi için, eğer bağlantıyı öğrenmişse, ürün yine de işlevine gönderme yapar, gösterge niteliğini sürdürür.

Kullanım ürünü tanınıyorsa, onu tanıyan kişide belli bir işlev çağrıştırır. Bu çağrışımın gerçekleşmesi için, onu kullanıyor olmamız gerekmez. Ürünü tanıyorsam, onu kullanmasam bile işlevinin ne olduğunu bilirim. Bu bilgiyi, daha önce okumasını öğrendiğim biçimin düzgülenmiş özellikleri aracılığıyla edinirim. Kısacası; ürün, biçimi aracılı̆̆ıyla kullanım işlevini çağrıştıran bir göstergedir. Ancak bununla kalmaz bu işleve eklemlenen diğer olgulara da gönderme yapar.

Burada tekrar ütü örneğimize dönelim. Buharlı ütü değişik görüntüsel gösterge özelliklerine sahiptir. Ancak bir yandan da bir alet olarak kabul görür. Buharlı ütünün biçimi, görüntüsel gösterge olarak pek çok olgu ve nesneye gönderme yapar. Örneğin; biçimsel benzeşim alanında, gemi, sürat teknesi, kuğu vb. gibi nesnelere. Bu arada kendisinin atatipine ve geleneksel biçimine de gönderme yapar. Biçim güvenliği, güvenli kullanım, teknik işlevinin güvenirliği vb. olguları çağrıştırır. Biçiminin risk taşımayan bildik bir biçim olduğunu yananlamlar.

Görüntüsel gösterge olarak buharlı ütü kendi geleneğine kayıtsız kalmayı da amaçlar. Gelenek yerine kullanım kolaylığı ve hız gibi kavramlarla ilgili bir biçime gönderme yapar. Ütünün biçimi, zaman ve kullanım enerjisi tasarrufu yapar gibi görünür. Hatta kendi kendine çalışabilecekmiş gibi de görünür. Üretim ve teknolojisine ilişkin göndermeler, üretimin niteliği ve bitmişlik fikrine göndermeler yapar. Bunların yanı sıra üreticisinin ve firmasının simgeleri aracılığıyla bunlara ilişkin göndermeler de yapar. Özetle yinelemek gerekirse, ürün göstergesi salt işlevini çağrıştırmakla kalmayan, değişik türden olgu ve olaylara göndermeler yapan bir karaktere sahiptir.

\section{Göstergesel açıdan biçim-işlev bağlantısının niteliği}

Ürün göstergesinde, gösteren yani anlatım kesimini ürünün biçimi oluşturuyordu. Gösterilen yani içerik kesimini ise ürünün kullanım işlevi ile buna eklemlenen diğer anlamlamalar oluşturur. Ürün göstergesinde biçim ile işlevin ilişkisinin kurulması bir anlamlamadır. Herhangi bir göstergede anlamlamanın (yorum) oluşabilmesi için; gösteren ile gösterilen arasındaki bağlantının kurulması gerekir. Ürün göstergesi açısından biçim ile işlev arasındaki bağlantının niteliği nedir? Bu bağlantı nasıl kurulur? Biçim ile işlev arasındaki ilişki; zorunlu nedenli bir bağ mıdır? Yoksa salt rastlantısal ve uzlaşımsal bir nitelikte midir? Ya da, fonksiyonalistlerin dediği gibi biçimi belirleyen işlev midir? $\mathrm{Bu}$ soruların yanıtları ürün göstergesindeki anlamlama bağlantısını açıklar.

Endüstri ürünleri tanımları gereği belirli kullanım işlevlerini karşılamayı amaçlayan kullanım nesneleridir. Kullanıcı gereksinimlerini ve ürünlerin pazarla olan ilişkilerini göz önüne aldığımızda, işlevini karşılamayan ürünlerin satmayacağını rahatlıkla söyleyebiliriz. Böyle bir olgunun tasarım söylemi içinde tartışması bile yapılmaz. Örneğin, fotoğraf çekemeyen bir fotoğraf makinası, kesmeyen bir bıçak, dikiş dikmeyen bir dikiş makinası, endüstri ürünü sayılamaz, olsa olsa şakalı bir nesne ya da bir sanat nesnesi olarak kabul görürler. Endüstri ürünlerinin işleve yönelmiş birer kullanım nesnesi olduğu kesindir. Tartışması yapılan; ürün biçimi ile işlevi arasında nasıl bir ilişkinin olması gerektiğidir.

$10 \mid$ Sayı II-12, 2011 
Sonradan "Bauhaus" okulunun sloganı haline gelen, Sullivan'ın ünlü deyişine göre "Biçim işlevi izler". Gerçekten biçimi belirleyen işlev midir? Aynı işleve yönelmiş ürünlerin, farklı biçimlerle sonuçlanmış olduğu gerçeğini nereye koyacağız? Ya da, biçim gerçekten zorunlu olarak işlevi izlerse, daha önce hiç bir karşılaşmamız olmayan bir nesneyi, biçimine bakarak ne olduğunu ve nasıl kullanıldığını çıkarabilir miyiz? Örneğin, Eco şöyle bir örnek verir: Sicilya köylerinden birinde hükümetin yaptı̆̆ 1 deprem evlerine taşınan köylüler, daha önce hiç karşılaşmadıkları "klozet" ile tanışırlar. Zeytincilikle uğraşan köylüler, olsa olsa mantığıyla davranarak bu yeni nesnenin zeytin yıkama kabı olarak hükümetin kendilerine bir armağanı olduğuna karar verirler. İçine yerleştirdikleri ağa doldurulan zeytinleri, sifonu çekerek kolaylıkla yıkarlar. Biraz şakalı bir hiciv taşıyan Eco'nun bu örneği, bize en azından şunu gösterir: köylüler kültürel yaşam alışkanlıklarından vazgeçemeyerek, yeni nesneyi kendileri için daha önemli bir işte kullanmayı tercih etmişlerdir. Burada dikkat çekmek istediğim nokta, kültürün nesneyi tanıma ve benimsemeyi yönlendirmesidir.

Kültürel ortamımızda yer almayan nesneleri benimsemek bir yana, biçimlerine bakarak işlevlerinin ne olduğunu yeterince açık olarak çıkarabilir miyiz? Eğer, doğrudan söz konusu işlevi tanımıyorsak, öyle bir işlevin yaşamımızda yeri yoksa, bu yeterince mümkün görünmüyor. Özellikle günümüzde, artan ürün çeşidi ve daha önce değindiğimiz örnekçe kaybı nedeniyle bu durum daha çok sorunlu bir hale gelmiştir.

Örneğin uzaktan ölçüm yapan "elektronik metre" ürününün, biçimine bakarak işlevini kestirmek olası değil. Bu ürün, onu tanımayan birisi için tamamen gizemli bir nesne gibi görülebilir.

Öte yandan aynı işleve yönelmiş ürün takımında, biçimlerin değişiklikler göstermesi de, malzeme ve teknolojinin, belki bir ölçüde de işlevin değişmiş olmasıyla açıklanabilir mi? $\mathrm{Bu}$ değişiklikler olsa da, olmasa da ürünlere yeni biçimler arayışı tasarımın doğasında vardır. O halde "biçim işlevi izler" deyişinin, misyonunu tamamlamış olduğunu söylememiz gerekecek. Aslında işlevselci bakış açısından bu slogan eşliğinde tasarlanan ürün biçimlerinin, en işlevsel olduğunu öne süren bir biçeme ait, biçim çözümleri olduğu açıktır. Ne var ki, ürün biçimiyle işlevi arasındaki ilişkinin de, dil göstergelerinde olduğu gibi nedensiz bir bağlantı olduğunu söyleyemeyiz. Zira, işlevini karşılamayan ve yerine getiremeyen bir biçim tasarlamak en baştan tasarımcı için anlamsızdır. İşlevini karşılamayan ürün biçimi de başarısızdır. Bunu söylerken doğaldır ki salt estetik işleve yönelmiş nesneleri endüstri ürünlerinden ayrı tutuyoruz. Endüstri ürünlerinin estetik görünümleri kullanım işlevini örtmeyen ya da dışlamayan çözümlerdir.

$\mathrm{Bu}$ açıklamalara dayanarak ürün göstergesinde, biçimle işlev arasındaki ilişkinin nedenli ve zorunlu bir bağlantı olduğunu söyleyebiliriz. Ancak bu bağlantı birebir karşılıklılık taşıyan bir ilişki değildir. Eğer öyle olabilseydi, işlevselcilerin dediği gibi "biçim işlevi izler"di. O zamanda bütün endüstri ürünlerinin kesin, şaşmaz bir tek biçimleri olurdu. Yeni çözümler, yeni biçimler, yeni biçemler gelişemezdi.

\section{Sonuç}

Sonuç olarak: Endüstri ürünleri biçimleri aracılığıyla işlevlerini çağrıştırdıkları için birer göstergedirler. Kullanılmıyor bile olsalar bu çağrıştırma işini yerine getirirler. Ancak, sadece biçimin kendisi işlevi tanımlamaya yetmez. Diğer göstergelerde olduğu gibi; 
gösterenle gösterilen (biçimle işlev) arasındaki bağlantıyı öğrenmiş olmak gerekir. (Sicilya köylülerinin örneğini anımsayarak söylemek gerekirse) bu bağlantının ürün bağlamında sosyal kültürel bir kodlama sürecine dayanması gerekir. Bu kültürel bağlam içinde söz konusu işlevi de öğrenmiş olmam, tanıyor olmam gerekir. Ancak o zaman biçim işlevi özendirebilir. Değişen sloganlarla ifade etmek gerekirse; "biçim işlevi açıklar" ama bu açıklama da; yine daha önce öğrendiklerimizin zemini üzerinde mümkün olabilir. Burada, Eco'nun deyişine bağlanarak; "biçim kültürü izler", denebilir. Biçimle işlev arasındaki bağlantıyı kuran kültürel kodlardır (code-şifre).

Üründe konumlanan tüm kültürel sosyal kodlamalar ile kullanım işlevinin tümüne; ürünün içeriği (content) dersek; ürün biçimi ile ürün içeriği arasındaki bağlantı zorunlu ve nedenli bir bağlantıdır. Bu en azından işlevin özendirilmesi ve yerine getirilmesine uygunluk açısından zorunlu ve nedenlidir. Ancak bu zorunluluk tasarımcıyı biçim çeşitlemeleri yapmaktan alıkoyan bir zorunluluk değildir. Aynı işleve yönelmiş ürünler değişik biçimlerde karşılanabilir. Bu nedenle ürün biçimi-ürün içeriği bağlantısı, değişmeyen, mutlak bir zorunluluk taşımayan, uzlaşımsal bir bağlantıdır.

Endüstri ürünlerini birer gösterge olarak görmek tasarımda hala oldukça yeni bir yaklaşımdır. Tasarım eyleminin kendisi bu göstergeyi üreten bir etkinlik, ürün ise bir gösterge olarak görüldüğünde, bu göstergebilimsel yaklaşım, tasarım alanında daha önce sözü edilmeyen bilgi ve tartışmaların ortaya çıkmasını sağlar. Ürün göstergeleri salt yalın biçim ve işlev açısından değil, taşıdığı türlü bilgi ve bildiriler nedeniyle kültürel bir biçim olarak algılanır ve araştırılır. Ürünlere bakarak onların belirli bir çevre, belirli bir insan grubu, belirli bir gelenek ve düşünce tarzına ait oldukları görülebilir.

Tasarım açısından temel sorun, söz konusu bilgi ve bildirilerin ürün göstergesi üzerinde nasıl konumlanacağına 1şık tutan, ürünü bir gösterge olarak görmektir. Göstergenin oluşum süreci ve gösterge türleri ve niteliklerine ait bilgi hem ürün göstergesini oluşturmayı yönlendirir hem de var olan ürün göstergelerini anlamamıza onları tanımlamamıza yardımcı olur. $\mathrm{Bu}$ özellikleri nedeniyle tasarım göstergebilimi, biçimdili betimlemelerinden daha ileri yararlar sunar. Tasarım göstergebilimi bir yandan tasarım etkinliği ve ürün göstergesine özgün betimlemeler getirirken, bir yandan da ürün çözümlemeleri yapacak bir bakışaçısını ve yöntemleri de tasarım alanına sunar.

Tasarım göstergebilimi, tasarım kuramlarına en özgün açıklamasını, tasarım alanının geleneksel işlev-biçim ilişkisini ve işlev anlayışını değiştirerek getirir. Ürün biçimi ile işlevi arasındaki ilişkiyi, gösteren gösterilen bağlantısı içinde yeniden tanımlar. Tasarım alanının geleneksel işlev anlayışını da iletişim işlevi içine katar. Bu yeni işlev ve biçim tanımını yöntemlere bağlayarak açıklar. Tasarım tarihine mal olmuş sloganları tersine çevirir ya da yeni bir içerikle bakmamızı sağlar. Tasarım göstergebilimi ürünü bir gösterge olarak görür ve tanımlar. Ürüne yüklenecek türlü bilgi ve bildirilerin hangi kurallar uyarınca üründe konumlanacağının yöntemsel araçlarını da verir. Bu araçlar aynı zamanda ürünü çözümlemede kullanılacak kuralları da verir.

Tasarım göstergebilimin, tasarım kuramlarına getirdiği yeni açıklama mantı̆̆ kuşkusuz tasarım eğitiminde sorunların ele alınış tarzını da etkiler. Öncelikle geleneksel biçim-işlev ilişkisinin tıkandığı alanlarda iletişim işlevi konuya farklı bir açılım getirir. Tasarım

12 sayı II-I2, 2011 
sorununun çözümünde ürün göstergesinin anlambilimsel işlevleri hem eğitime hem de tasarımcıya farklı araçlar sunar.

Tasarımcı ile kullanıcı arasında yer alan ortak gösterge birikiminin ve göstergelerin düzgülenme kurallarının bilinmesi, ürün göstergesinin kullanıcılar tarafından en uygun yorumlanma koşullarının nasıl yaratılacağı sorusunu gündeme getirir. Bu anlamda yalın kavramların yine yalın biçimli ürünlerle okunurluk ve yorum koşullarının denendiği çalışmalar tasarıma giriş dersi kapsamında ele alınabilir. Ürün göstergesinin anlambilimsel işlevleri olan; betimleme, anlatım, işaret- etme ve kimliklendirme işlevleri tasarım sürecine, ürünün karekterine bağlı olarak yol gösterebilir. Yine ürün karekterine bağlı olarak bu işlevlerden hangisinin daha ağırlıklı olarak vurgulanacağı, tasarım hedeflerinin seçimi aşamasında süreçe yardımcı olur.

Tasarım göstergebilimi tasarım alanına sunduğu özgün açıklamalarla, tasarım sorunlarına salt işlev ölçütü açısından bakılma sakıncasını ortadan kaldırır. Tasarım eleştirisine yöntemler getirerek göreli açıklamalara gerek bırakmaz. Daha önce adı konulamıyan ürün ilişkilerine, ürün göstergesinin gireceği gösterge sınıfına ve sınıfın niteliğine bağlı olarak açıklamalar getirme olanağı sunarø

\section{KAYNAKÇA}

Bayrakçı, Oğuz. 1985. Tasarım Eylemi ve Nesnelerinde Yapısal İlişkilerin Betimlenmesine Göstergebilimsel Bir Yaklaşım ve Yöntem Araştırması. Doktora tezi. Mimar Sinan Üniversitesi.

Bayrakçı, Oğuz. 1985. Tasarımda Anlamlama ve Dil. Yapı Dergisi. s.60 1985/2.

Bayrakçı, Oğuz. 2004. Çağdaş İletișim Kuramları Açısından Tasarımda İletişimsel Modeller. Basım: MSGSÜ, Mim. Fak. Yayın

Erkman, Fatma. 1987. Göstergebilime Giriş. İstanbul: Alan Yay.

Umberto, Eco. 1980. Function and Sign: The Semiotic of Architecture. Sign, Symbol and Architecture. (eds) G. Broadbent, R. Bunt, C. Jencks. John Wiley and Sons New York.

Vardar, Berke. 1988. Açıklamalı Dilbilim Terimleri Sözlüğü. İstanbul: ABC Kitapevi.

Vakeva, Seppo. 1990. What Do We Need Semiotics For Semantic visions in Design. Symposium on Design Reseach and Semiotics. 1989. Ed. S. Vihma, Helsinki.

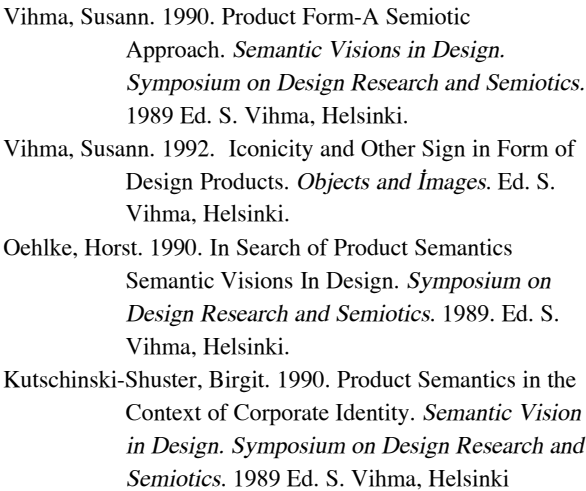

Oehlke, Horst. 1990. In Search of Product Semantics Semantic Visions In Design. Symposium on Design Research and Semiotics. 1989. Ed. S. Vihma, Helsinki.

Kutschinski-Shuster, Birgit. 1990. Product Semantics in the Context of Corporate Identity. Semantic Vision in Design. Symposium on Design Research and Semiotics. 1989 Ed. S. Vihma, Helsinki 